\title{
EMPIRICAL DATA ON FINANCIAL AND AUDIT REPORTS OF SERBIAN BUSINESS ENTITIES
}

\author{
Vule Mizdrakovići ${ }^{1 *}$ \\ Nenad Stanić, \\ Vladimir Mitic ${ }^{1,2}$ \\ Ana Obradović, ${ }^{1,2}$ \\ Maja Kljajicí, ${ }^{1,}$ \\ Maja Obradović1,2, \\ Nemanja Stanišić ${ }^{1}$ \\ ${ }^{1}$ Singidunum University, \\ Belgrade, Serbia \\ ${ }^{2} \mathrm{PhD}$ candidate, \\ Singidunum University, \\ Belgrade, Serbia
}

\begin{abstract}
:
The aim of this paper is to create a one of a kind database that will provide basic information collected from financial and audit reports of companies that operated in the Republic of Serbia, during the observed period 2016-2018. Interested researchers can use all information presented within the database without additional permission, if they provide appropriate referencing of this paper while publishing their research results. Data contained in the database were collected manually from the official Internet website of the Business Registers Agency of the Republic of Serbia. The database shows a total of 9,549 annual observations, by years: 2016: 3,242, 2017: 3,197, 2018: 3,110. Most commonly used financial indicators that measure liquidity, solvency and profitability of observed companies were calculated and included in the database, but interested researchers will be able to calculate other indicators if needed. Information presented in the database can serve as a good basis for further analysis and research in the field of accounting, auditing and other multidisciplinary fields. Complete database can be found on the following link: https:/data.mendeley.com/datasets/ x3z4zx8vwr/draft?a=2851c2e4-afc0-4d60-b2de-ce1fa1b27a30.
\end{abstract}

\section{Keywords:}

database, financial indicators, financial statements, audit reports, Business Registers Agency.
Correspondence:

Vule Mizdraković

e-mail:

vmizdrakovic@singidunum.ac.rs

\section{INTRODUCTION}

Financial and audit reports are the main source of information for business decision making process, as they contain key information about company's financial position, financial results, changes in equity, cash flows and other relevant information (Mrvaljevic, Dobricanin, \& Đuricanin, 2014). These reports present significant source of data that can be used in scientific research, both in the field of economics and in multidisciplinary research. Most important feature of financial and audit reports, as secondary sources of research, is their availability. Namely, the Law on Accounting of the Republic of Serbia requires from all legal entities to submit their reports to the Business Registers Agency, which are later disclosed on the Agency's official website (Official Gazette of the Republic of Serbia No. 73/2019, 2019). Law on Auditing of the Republic of Serbia prescribes mandatory audit of financial statements for: medium, large, parent legal entities for consolidated financial statements; and all other legal entities that recorded more than 4,400,000 euros of revenues in the previous reporting period (Official Gazette of the Republic of Serbia No. 73/2019, 2019). Main purpose of audit report is to increase the level of credibility of audited financial statements by disclosing audit opinion. Although information presented in both financial statements and audit reports could be used for different scientific purposes, the time needed to collect and pre-process information from the published reports can be very time and labor consuming. 
Namely, all reports have to be downloaded manually and individually, afterwards each value needed for research have to be copied and recorded in pre-set tables suitable for the analysis. Therefore, main goal of this paper is to provide a database that contain empirical data related to financial and audit reports of Serbian business entities that will be available and ready to use by all interested researchers.

\section{RESEARCH METHODOLOGY}

Research sample consists of mostly medium and large business entities that were selected by random. Financial statements and related audit reports have been downloaded manually from the official website of the Business Registers Agency. After that, data from the pdf files have been copied and recorded in pre-set up tables in Excel files. In addition, values originally disclosed in RSD, as the reporting currency, were converted into euros by using the average exchange rate of euros on the balance sheet date $\left(31^{\text {st }}\right.$ December). Values in database will be presented in thousands, since they were originally disclosed in thousand RSD in financial statements. As mentioned above, not all business entities had audit reports publicly available, because financial statement audit is mandatory for selected entities.

When it comes to audit reports, following information was recorded: name of audit company, name and surname of the auditor that signed the report and report date. It is important to mention that some entities were not subject to audit or simply did not publish audit reports, therefore NA (Not Available) ${ }^{1}$ have been entered for them in the corresponding cells. Errors in stated date of the report were noticed in several audit reports and were corrected accordingly. Total number of auditing companies hired by sampled entities is 77 , and they were divided by type to: local, international ${ }^{2}$ and Big 4 companies. Namely, all audit companies operated within the territory of Republic of Serbia, but the first group are the ones that do not belong to an international group (parent company or subsidiary). Numerous authors (Berglund, Eshleman, \& Guo, 2018) (Fargher, Jiang, \& Yu, 2017) (Gaynor, Kelton, Mercer, \& Yohn, 2016) (Swanquist \& Whited, 2015) investigated the association between the size and methodology used by auditing companies and audit quality and other aspects of audit client business. Some of them found an evidence that Big 4 companies provide audits of higher quality (Eshleman \& Guo, 2014). Therefore, dividing audit companies to Big 4, international and local might be helpful for all authors that will use database as a result of this research.

1 This will be used for all values that were missing in the reports, or when calculated values of financial indicators are infinite.

2 Also known as mid-tier audit companies.
According to the revised version of International Standard on Auditing (ISA) 700 - Forming an Opinion and Reporting on Financial Statements, auditors have an obligation to clearly state in a separate paragraph which audit opinion type is declared within the audit report (IAASB, 2015). Therefore, authors have been able to discern which audit opinion type client received without any issues in most cases. Opinion types have been divided to four groups: Unqualified Opinion, Emphasis of Matter Paragraphs, Qualified Opinion, Disclaimer of Opinion and Adverse Opinion. Afterwards, gender of a signatory of the report has been determined based on the name of the auditor. This information can be of interest to researchers that focus on the gender equality within audit companies or even the correlation between audit opinion type and gender of report signatory. There has been one report where auditor name was missing; therefore, gender could not be determined.

Basic information on sampled business entities, such as identification number and the name of the entity have been collected. Afterwards, financial statement items from Balance Sheet, Income Statement and Statement on Cash Flows for reporting period 2016-2018 have been recorded. Those three statements have been selected since the most common financial indicators are calculated based on the information from those statements. Financial statement items will be presented in database by using corresponding automatic data processing number (in Serbian: Automatska obrada podataka - AOP), that belong to the national nomenclature system. Balance sheet items cover automatic data processing numbers from 0001 to 0465 , income statement from 1001 to 1071 and statement of cash flows from 3001 to 3047. Table 1 shows the formulas used for the calculation of the financial indicators present in the dataset $^{3}$.

3 Interpretations of selected financial indicators can be found here: (Knezevic, Stanisic, \& Mizdrakovic, 2017). 
Table 1. Calculation of selected financial indicators

\begin{tabular}{|c|c|}
\hline Financial indicator & Calculation \\
\hline Total Assets & AOP 0071 \\
\hline Net Equity & AOP 0401 \\
\hline Operating Revenue & AOP 1001 \\
\hline Operating Result & AOP 1030 (gain) or AOP 1031 (loss) \\
\hline Net Result & AOP 1064 (gain) or AOPP 1065 (loss) \\
\hline EBIT & $($ AOP 1058 or AOP 1059) + AOP 1046 \\
\hline EBITDA & $($ AOP 1058 or AOP 1059) + AOP 1046 + AOP 1027 \\
\hline NOPLAT & EBIT $\times(1-$ corporate tax rate $)$ \\
\hline Debt Ratio & $(\mathrm{AOP} 0424+\mathrm{AOP} 0441+\mathrm{AOP} 0442) / \mathrm{AOP} 0071$ \\
\hline Interest Bearing Debt Ratio & $(\mathrm{AOP} 0432+\mathrm{AOP} 0443) / \mathrm{AOP} 0071$ \\
\hline Working Capital & AOP 0043 - AOP 0442 \\
\hline Current Ratio & AOP 0043 / AOP 0442 \\
\hline Acid Test Ratio & (AOP 0043 - AOP 0044 - AOP 0069 - AOP 0070) / AOP 0442 \\
\hline Cash Ratio & AOP 0068 / AOP 0442 \\
\hline Net Margin & (AOP 1064 - gain or AOP 1065 - loss) / AOP 1001 \\
\hline Return on Equity (ROE) & (AOP 1064 - gain or AOP 1065 - loss) / AOP 0401 \\
\hline Operating Margin & (AOP 1030 - gain or AOP 1031 - loss) / AOP 1001 \\
\hline Return on Assets (ROA) & (AOP 1030 - gain or AOP 1031 - loss) / AOP 0071 \\
\hline Excess Cash & Excess amount of: AOP $0068-(3 \% \text { x AOP 1001 })^{4}$ \\
\hline Return on Invested Capital & EBIT $\times(1$ - corporate tax rate $) /($ AOP $0401+$ AOP $0432+$ AOP $0443-$ Excess Cash $)$ \\
\hline Return on Core Assets & (AOP 1030 - gain or AOP 1031 - loss) / (AOP 0071 - AOP 0024 - AOP 0062 - Excess Cash) \\
\hline Days Sales Outstanding & AOP 0051/ (AOP $1002+$ AOP 1009) × $365 / 1.2^{5}$ \\
\hline Days Payable Outstanding & $\begin{array}{l}\text { AOP } 0451 /(\text { AOP } 1019+\text { AOP } 1020+\text { AOP } 1021-\text { AOP } 1022+\text { AOP } 1023+\text { AOP } \\
1024+\text { AOP } 1026+\text { AOP 1029) } \times 365\end{array}$ \\
\hline Days of Inventory & $\begin{array}{l}(\text { AOP } 0045+\text { AOP } 0046+\text { AOP } 0047+\text { AOP 0048) } /(\text { AOP } 1019+\text { AOP } 1020+ \\
\text { AOP } 1021-\text { AOP } 1022+\text { AOP } 1023) \times 365 \times 1,2\end{array}$ \\
\hline Cash Conversion Cycle & Days Sales Outstanding - Days Payable Outstanding + Days of Inventory \\
\hline Z-score Private Companies & $\begin{array}{l}0.717 \times((\text { AOP } 0043-\text { AOP 0442 }) / \text { AOP 0071) }+0.847 \times(\text { AOP } 0417 / \text { AOP } 0071)+ \\
3.107 \times(\text { EBIT / AOP 0071 })+0.420 \times(\text { AOP } 0401 /(\text { AOP } 0424+\text { AOP } 0441+\text { AOP } \\
0442))+0.998 \times(\text { AOP } 1001 / \text { AOP 0071 })\end{array}$ \\
\hline $\begin{array}{l}\text { Z-score Non-manufacturing Firms and } \\
\text { Emerging Markets }\end{array}$ & $\begin{array}{l}6.56 \times((\mathrm{AOP} 0043-\mathrm{AOP} 0442) / \mathrm{AOP} 0071)+3.26 \times(\text { AOP } 0417 / \text { AOP } 0071)+6.72 \\
\times(\mathrm{EBIT} / \mathrm{AOP} 0071)+1.05 \times(\mathrm{AOP} 0401 /(\mathrm{AOP} 0424+\mathrm{AOP} 0441+\mathrm{AOP} 0442))\end{array}$ \\
\hline Free Cash Flow to Equity (FCFE) & AOP 3047 - AOP 3044 + AOP 3037 + AOP 3032 - AOP 3026 \\
\hline Free Cash Flow to Firm (FCFF) & $\begin{array}{l}\text { FCFE - AOP } 3027 \text { - AOP } 3028+\text { AOP } 3033+\text { AOP } 3034+\text { AOP } 3008 \times(1-\text { corpo- } \\
\text { rate tax rate) }\end{array}$ \\
\hline Interest Coverage Ratio & EBIT / AOP 1046 \\
\hline Fixed Assets in Total Assets & AOP 0002 / AOP 0071 \\
\hline Dividend Payout Ratio & AOP 3037 / (AOP 1064 - AOP 1065) \\
\hline Effective Tax Rate & AOP 1060 / AOP 1058 \\
\hline Interest Rate on Interest-bearing Debt & AOP $1046 /($ AOP $0432+$ AOP 0443) \\
\hline Implied Growth Rate & ROE $\times(1$ - Dividend Payout Ratio $)$ \\
\hline Sustainable Growth Rate & $\begin{array}{l}(\text { Net Margin } \times(1-\text { Dividend Payout Ratio }) \times(1+((\text { AOP } 0424+\text { AOP } 0441+\text { AOP } 0442) \\
/ \text { AOP 0401) }) /(\text { AOP } 0071 / \text { AOP } 1001-(\text { Net Margin } \times(1-\text { Dividend Payout Ratio }) \\
\times(1+((\text { AOP } 0424+\text { AOP } 0441+\text { AOP } 0442) / \text { AOP 0401 })))\end{array}$ \\
\hline
\end{tabular}

40 if the value is negative.

5 Account Receivables includes VAT of $20 \%$ in the Republic of Serbia, however sales revenues do not include VAT. Therefore, coefficient 1.2 is used to exclude that amount from the amount of receivables. 


\section{RESEARCH RESULTS}

Descriptive statistics will be presented in this section. Dataset provided as a result of this research contains information from 9,549 annual financial statements and corresponding audit reports (where available).
Collected data have been used to calculate basic figures when it comes to financial and audit reports. Table number 2 shows following information per reporting period: number of processed reports, audit opinion type, auditor gender and auditor type.

Table 2. Basic information on audit reports included in the database

\begin{tabular}{|c|c|c|c|c|}
\hline Reporting period & 2016 & 2017 & 2018 & Total \\
\hline Financial statements & 3,242 & 3,197 & 3,110 & 9,549 \\
\hline Audit reports & 2,170 & 2,100 & 2,073 & 6,343 \\
\hline Unqualified opinion & 1,101 & 1,093 & 1,137 & 3,331 \\
\hline Emphasis of matter paragraphs & 446 & 454 & 440 & 1,340 \\
\hline Qualified opinion & 478 & 414 & 386 & 1,278 \\
\hline Disclaimer of opinion & 127 & 121 & 96 & 344 \\
\hline Adverse opinion & 18 & 18 & 14 & 50 \\
\hline Male auditors & 1,198 & 1,090 & 1,055 & 3,343 \\
\hline Female auditors & 971 & 1,010 & 1,018 & 2,999 \\
\hline Audits performed by local audit firms & 1,077 & 1,075 & 1,073 & 3,221 \\
\hline $\begin{array}{l}\text { Audits performed by international audit } \\
\text { firms }\end{array}$ & 708 & 654 & 664 & 2,026 \\
\hline Audits performed by Big 4 & 385 & 371 & 336 & 1,092 \\
\hline
\end{tabular}

Source: Authors' research

Most common audit opinion is unqualified, which together with opinions with emphasis of matter paragraphs consist $73.64 \%$ of total sample. Out of modified opinions, qualified opinion is the most common, as sample auditors gave 1,278 out of 1,672 modified opinions. Unsurprisingly, adverse opinion is the rarest out of all declared audit opinions. Audit clients from the sample received their audit reports in 140.73 days (or app. 4 months and 20 days). Average values per year were very close to previous value, 142.31 in 2016, 140.32 in 2017 and 139.51 in 2018. This lag is actually longer than the one recorded on 196 Serbian public companies of 117.46 days, back in 2015 (Obradovic, Mizdrakovic, \& Avlijas, 2018). Explanation might be that audit firms were aware that public companies are more eager in getting audit reports because their future investments might depend on them. Furthermore, it can be noticed that there is almost a perfect balance in hiring auditors of both gender by Serbian audit clients. Namely, out of 6,343 audit reports, male auditors signed 3,343 (app. 52.7\%) reports and female auditors (app. 47.3\%) signed remaining amount.

Since 2015, after the financial crisis, the level of investments in Serbia has been growing, which is conducive to even greater reduction in unemployment and an increase in GDP (Jakopin, 2018). There is a positive trend here and it can be confirmed by the announcements provided by previously mentioned Business Registers Agency (BRA). In 2016, entities earned 534,412 million dinars of positive net result, while in 2017 they earned 666,561 million dinars (about 32\% more than previous year). Business entities in Serbia as a whole operated profitably in 2018 and achieved a positive net result of approx. RSD 500 billion. Namely, positive net result amounted to about RSD 746 billion while the loss amounted to about RSD 246 billion. In addition, in 2018; 60,566 companies operated with a profit (about $69 \%$ ), while 27,272 (about 31\%) operated with a loss. There is also a positive trend as the number of entities that had losses decreases: in $2016(27,194)$ and in 2017 (26,592), while the number of companies operating with profit in $2016(57,160)$ and in 2017 increases $(59,131)$.

Median values of calculated financial indicators that measure profitability of sampled Serbian entities confirm previously stated. Net result of sampled entities remained positive during the observed period; it increased by approx. 22\% in 2017 and then decreased in 2018. Median values of operating result however recorded a decrease of approx. 13\% from 2016 to 2018. Previous suggests that sampled entities recorded positive result from financing and other (non-business) related activities, which ultimately resulted in an increase of net result. It is interesting to notice that despite the volatility of net result, 
median value of net margin remained the same during the period, close to $1 \%$, which means that net result followed changes of sales revenue.

Although sampled entities were profitable, they were not highly liquid at the same time. Namely, average values of current and acid test ratios might lead to conclusion that sampled entities are liquid (average value of current ratio reaches approx. 15), however median values reveal that their amount is lower than required 2 and 1, respectively. Bankrupt entities close to the end of bankruptcy proceedings usually have high amounts of cash and cash equivalents as they already liquidated their assets, therefore values of cash they own are actually extreme values in this dataset. Previous might be an explanation why there is such a high discrepancy between average and median values of indicators that measure liquidity. When it comes to the return on invested assets and equity, their median values recorded a decrease of approx. 1\% during the period (approx. 3\% for ROA and approx. $6 \%$ for ROE). It is interesting to notice that values are close to the ones reported by (Stanisic, Radojevic, Mizdrakovic, \& Stanic, 2012) back in 2011; and much lower than the ones from 2008 when ROE was close to $20 \%$ of entities from Belgrade region.

Table 3. Median values of selected financial indicators

\begin{tabular}{|lrrr|}
\multicolumn{1}{c}{ Financial indicator } & \multicolumn{2}{r}{2016} & 2018 \\
\hline Operating result & 166.65 & 150.54 & 145.12 \\
\hline Net result & 103.97 & 126.71 & 112.73 \\
Net margin & .75 & .81 & .80 \\
\hline Debt ratio & .53 & .52 & .52 \\
Current ratio & 1.28 & 1.32 & 1.32 \\
Acid test ratio & .74 & .76 & .76 \\
ROA & $4.12 \%$ & $3.56 \%$ & $3.15 \%$ \\
ROE & $7.49 \%$ & $7.59 \%$ & $6.25 \%$
\end{tabular}

Source: Authors' research

\section{CONCLUSION}

Information contained in financial statements and audit reports are almost mandatory for any kind of research within finance, accounting, auditing and other fields. Although those reports are available for the public in the Republic of Serbia, interested researchers are not able to acquire needed information for a higher number of business entities without significant amount of time and labor. Research results of this paper provide unique database that is available for use by all interested users, with a condition of appropriate referencing in their scientific papers. Database contains information from 9,549 annual financial statements and 6,343 corresponding audit reports of business entities that operated during 2016-2018 reporting period. Additionally, interested researchers will be able to calculate any financial indicator that is calculated by using any item from Balance Sheet, Income Statement and Statement of Cash Flow. Combined with the information from corresponding reports, data can be used to inspect different aspects related to audit quality, earnings management, prediction of bankruptcy proceedings and others. Beside fellow researchers and PhD students, potential users of this database might be management of audit companies and other business entities, financial institutions, tax authorities, financial market analysts, etc.
Finally, some of the most common financial indicators have been calculated and included in the database, as potential researchers will most likely use them in their research. Brief analysis of the information shows that business entities operated with profit during the observed period; however, median values of liquidity indicators are below required level. Approximately three quarters of audit clients received unqualified opinion, local audit companies have performed half of audits, and there is almost a perfect balance when it comes to the gender of auditor in charge.

\section{LITERATURE}

Anicic, J., Kvrgic, G. \& Anicic, D. (2017). Poslovanje privrede Srbije u 2016 godini - Finansijski aspekt. Economics of Sustainable Development, 2(1), 31-37.

Berglund, N., Eshleman, J. \& Guo, P. (2018). Auditor Size and Going Concern Reporting. Auditing, 37(2), 1-25.

Eric, D., Beraha, A., Djuricin, O., Kecman, Dj. \& Jakišić, B. (2012). Finansiranje malih i srednjih preduzeća u Srbiji. Beograd:Institut ekonomskih nauka, Privredna komora Srbije.

Eshleman, J. \& Guo, P. (2014). Do Big 4 Auditors Provide Higher Audit Quality after Controlling the Endogenous Choice of Auditor. Auditing, 33(4), 197-219. 
Fargher, N., Jiang, A. \& Yu, Y. (2017). Further Evidence on the Effect of Regulation on the Exit of Small Auditors from the Audit Market and Resulting Audit Quality. Auditing, 34(4), 95-115.

Gaynor, L., Kelton, A., Mercer, M., \& Yohn, T. (2016). Understanding the Relation between Financial Reporting Quality and Audit Quality. Auditing, 35(4), 1-22.

IAASB. (2015). International Standard on Auditing (ISA) 700 (Revised), Forming an Opinion and Reporting on Financial Statements. Retrieved from International Auditing and Assurance Standards Board. Available at: https:// www.iaasb.org/publications/international-standard-auditing-isa-700-revised-forming-opinion-and-reportingfinancial-statements- 5

Jakopin, E. (2018). Privredni rast i institucionalna tranzicija Republike Srbije. Ekonomski horizonti, 20(2), 95-108.

Knezevic, G., Stanisic, N. \& Mizdrakovic, V. (2017). Analiza finansijskih izveštaja - drugo izmenjeno i dopunjeno izdanje. Belgrade:Singidunum University.

Laketa, M. \& Laketa, L. (2013). Klasteri kao model povezivanja malih i srednjih preduzeća u funkciji oživljavanja privrede Srbije. EMC Review - Economy and market, 6(2), 200-215.
Mrvaljevic, M., Dobricanin, S., \& Đuricanin, J. (2014). Finansijski izveštaji u funkciji menadžment odlučivanja. Ekonomski signali, 9(2), 85-103.

Obradovic, A., Mizdrakovic, V. \& Avlijas, G. (2018). Analysis of Audit Report Lag on Serbian Stock Exchange. Finiz 2018 (pp. 113-117). Belgrade: Singidunum University.

Official Gazette of the Republic of Serbia No. 73/2019. (2019). Accounting Law.

Official Gazette of the Republic of Serbia No. 73/2019. (2019). Audit Law.

Stanisic, N., Radojevic, T., Mizdrakovic, V. \& Stanic, N. (2012). Capital Efficiency Analysis of Serbian Companies. Journal of Applied Sciences, 9(2), 41-49.

Swanquist, Q., \& Whited, R. (2015). Do Clients Avoid "Contaminated" Offices? The Economic Consequences of Low-Quality Audits. The Accounting Review, 90(6), 2537-2570. 